\title{
A Relatively High Number of Pregnant Women in Kuwait Remain Susceptible to Rubella: A Need for an Alternative Vaccination Policy
}

\author{
Nada Madi Haya Al-Tawalah Dina Abdul Khalik Widad Al-Nakib \\ Virology Unit, Department of Microbiology, Faculty of Medicine, Kuwait University, Safat, Kuwait
}

\section{Key Words}

Rubella $\cdot$ Hepatitis B · Pregnant women · Kuwait

\begin{abstract}
Objective: To measure the prevalence of anti-rubella lgG and hepatitis B surface antigen ( $\mathrm{HBsAg}$ ) among pregnant women in Kuwait in order to assess the effectiveness of the current vaccination programs. Subjects and Methods: This retrospective study involved 4,062 pregnant women evaluated in health centers in the Hawalli Province of Kuwait. They were screened for anti-rubella IgG and HBsAg using commercially available assays. The data were obtained from medical laboratory records. Results: The mean age of the pregnant women was $29.2 \pm 5.26$ years (range 17-49). The rubella IgG prevalence among the pregnant women was $88.4 \%(n=3,589) ; 276(6.8 \%)$ of the pregnant women had no antibody to rubella, and 197 (4.8\%) had rubella antibody levels $\leq 10 \mathrm{IU} / \mathrm{ml}$. Therefore, 473 (11.6\%) of the pregnant women were susceptible to rubella. The proportion of susceptible women increased with increasing age from 3.4 to $10.3 \%$ and from 3.4 to $6.7 \%$ among women aged $<20$ years and those aged $\geq 40$ years, respectively $(p=0.016)$. The prevalence of HBsAg was $0.3 \%$, and it did not vary with age. Conclusion: The prevalence of both anti-rubella IgG and HBsAg among
\end{abstract}

pregnant women in Kuwait was relatively high. However, about $11.6 \%$ of pregnant women in Kuwait remain susceptible to rubella infection and hence congenital infection and fetal malformation.

(c) 2014 S. Karger AG, Base

\section{Introduction}

Rubella, also called German measles, is a disease of childhood that has markedly declined in incidence due to routine childhood rubella vaccination [1]. Primary infection with the rubella virus results in a mild, self-limiting disease in the majority of cases. However, infection during pregnancy results in severe manifestations to the fetus. Maternal rubella infection is associated with spontaneous abortion, intrauterine death, severe alterations in fetal growth and development, microcephaly, cataracts, hepatosplenomegaly, heart disease, deafness, meningitis, and other disorders [2-4]. In many countries, rubella seropositivity ranges between 54.1 and $95 \%$ among women of childbearing age $[5,6]$. Absence or low levels $(\leq 10 \mathrm{IU} /$ $\mathrm{ml}$ ) of rubella IgG before or during the first trimester of pregnancy identifies women who may be at risk of infection and hence congenital transmission of the virus [7].

\begin{tabular}{ll}
\hline KARGER & $\begin{array}{l}\text { @ 2014 S. Karger AG, Basel } \\
1011-7571 / 14 / 0232-0145 \$ 39.50 / 0 \quad \text { Karger }\end{array}$ \\
E-Mail karger@karger.com & $\begin{array}{l}\text { This is an Open Access article licensed under the terms of the } \\
\text { Creative Commons Attribution-NonCommercial 3.0 Un- } \\
\text { ported license (CC BY-NC) (www.karger.com/OA-license), } \\
\text { applicable to the online version of the article only. Distribu- } \\
\text { tion permitted for non-commercial purposes only. }\end{array}$
\end{tabular}

Nada Madi

Department of Microbiology

Faculty of Medicine, Kuwait University

PO Box 24923, Safat 13110 (Kuwait)

E-Mail madi@hsc.edu.kw 
Table 1. Frequency of seropositive and seronegative tests for anti-rubella IgG and HBs Ag among Kuwaiti and non-Kuwaiti pregnant women and among different age groups

\begin{tabular}{|c|c|c|c|c|c|c|c|c|c|}
\hline & \multicolumn{4}{|c|}{ Rubella IgG } & $\mathrm{p}$ & \multicolumn{3}{|l|}{ HBsAg } & $\mathrm{p}$ \\
\hline Kuwaiti & $66(4.5)$ & $97(6.7)$ & $1,294(88.8)$ & 1,457 & & $1,452(99.7)$ & $5(0.3)$ & 1,457 & \\
\hline Non-Kuwaiti & $210(8.1)$ & $100(3.8)$ & $2,295(88.1)$ & 2,605 & & $2,597(99.8)$ & $6(0.2)$ & 2,603 & \\
\hline Total & $276(6.8)$ & $197(4.8)$ & $3,589(88.4)$ & 4,062 & & 4,049 (99.7) & $11(0.3)$ & 4,060 & \\
\hline $20-29$ years & $118(5.6)$ & $104(4.9)$ & $1,898(89.5)$ & 2,120 & & $2,111(99.6)$ & $8(0.4)$ & 2,119 & \\
\hline $30-39$ years & $139(8.1)$ & $80(4.7)$ & $1,719(87.3)$ & 1,719 & & $1,716(99.9)$ & $2(0.1)$ & 1,718 & \\
\hline$\geq 40$ years & $17(10.3)$ & $11(6.7)$ & $137(83.0)$ & 165 & & $164(99.4)$ & $1(0.6)$ & 165 & \\
\hline Total & $276(6.8)$ & $197(4.8)$ & $3,589(88.4)$ & 4,062 & & 4,049 (99.7) & $11(0.3)$ & 4,060 & \\
\hline
\end{tabular}

Values are given as numbers (\%). ND = Not detected (seronegative).

Hepatitis B is one of the world's major public health problems, affecting about 350 million people (about 5\% of the human population) [8]. Whether the hepatitis $\mathrm{B}$ virus (HBV) infection becomes chronic mainly depends on the age of the individual at time of infection. The prevalence rate of chronicity among infants and young children born to women who are carriers varies between 30 and $90 \%$, whereas among adults the rate of chronic infection varies between 5 and $10 \%$ [8-11]. Therefore, the best strategy to prevent chronic HBV infection is to immunize all newborns against hepatitis $B$, especially infants who are at risk of infection from their $\mathrm{HBV}$-carrying mothers [9].

This retrospective study aims to determine the prevalence of rubella IgG antibody and hepatitis B surface antigen (HBsAg) among pregnant women attending health centers in the Hawalli Province of Kuwait.

\section{Subjects and Methods}

This retrospective study was conducted between December 2012 and February 2013 in a group of pregnant women aged $<20$, $20-29,30-39$, and $\geq 40$ years. A total of 4,062 pregnant women were referred to different health clinics in the Hawalli Province for pregnancy-related health checks. The study population was divided into 4 groups based on age for analysis: <20, 20-29, 30-39, and $\geq 40$ years. Screening for rubella IgG antibody and HBsAg was performed in the Virology Unit of the Faculty of Medicine of Kuwait University in Kuwait. These tests are done routinely as part of prenatal blood care in Kuwait.

A sample of $5 \mathrm{ml}$ was collected from each pregnant woman and sera were stored at $-20^{\circ} \mathrm{C}$ until testing. Sera were analyzed for anti-rubella IgG and HBsAg using commercial microparticle enzyme immunoassays (ARCHITECT i1000SR and ARCHITECT i2000SR Systems; Abbott Laboratories, Abbott Park, Ill., USA). The assays were performed according to the manufacturer's instructions. Levels $\geq 10 \mathrm{IU} / \mathrm{ml}$ were regarded as positive protective levels for anti-rubella IgG, whereas levels of rubella IgG $<10 \mathrm{IU} / \mathrm{ml}$ were considered to be susceptible. Index values for the HBsAg level were determined according to the assay.

Statistical Package for Social Science (SPSS, version 17.0) software was used for statistical analysis. A $\chi^{2}$ test was used to calculate statistical differences between proportions. $\mathrm{p}<0.05$ was considered statistically significant.

\section{Results}

A total of 4,062 pregnant women were enrolled into this study. The collected samples were convenience samples. The mean age was $29.2 \pm 5.26$ years (range $17-49$ ). The highest percentage $(2,120 ; 52.2 \%)$ of pregnant women who were tested for anti-rubella IgG and HBsAg were aged between 20 and 29 years, while only 58 (1.4\%) of the pregnant women were aged $<20$ years. Of these pregnant women, 2,605 (64.1\%) were non-Kuwaiti, whereas 1,457 (35.9\%) were Kuwaiti. The non-Kuwaiti women were from different countries because many nationalities work in Kuwait.

The prevalence of rubella antibody among pregnant women in Kuwait was $88.4 \%(\mathrm{n}=3,589)$, while $6.8 \%$ $(\mathrm{n}=276)$ were seronegative for rubella. Furthermore, $4.8 \%(\mathrm{n}=197)$ had levels of rubella IgG $<10 \mathrm{IU} / \mathrm{ml}$. Therefore, $473(11.6 \%)$ of the pregnant women were susceptible to rubella. Of the 473 susceptible women, 163 (4\%) were 
Kuwaiti and 310 (7.6\%) were non-Kuwaiti. Among the 1,457 Kuwaiti pregnant women, 1,294 (88.8\%) had high levels $(\geq 10 \mathrm{IU} / \mathrm{ml})$ of anti-rubella IgG. Ninety-seven $(6.7 \%)$ had antibody levels $<10 \mathrm{IU} / \mathrm{ml}$ and $66(4.5 \%)$ were seronegative. Of the 2,605 non-Kuwaiti pregnant women, 2,295 (88.1\%) also had high levels of anti-rubella IgG (table 1$)$, while $100(3.8 \%)$ had antibody levels $<10 \mathrm{IU} / \mathrm{ml}$ and $210(8.1 \%)$ were seronegative. The prevalence of HBsAg among pregnant women in Kuwait was only $0.3 \%$ (table 1) and it was similar among both Kuwaiti and nonKuwaiti women.

The proportion of pregnant women who were seronegative for anti-rubella IgG or had levels $\leq 10 \mathrm{IU} / \mathrm{ml}$ increased with increasing age from 3.4 to $10.3 \%$ and from 3.4 to $6.7 \%$ among women aged $<20$ years and those aged $\geq 40$ years age, respectively $(\mathrm{p}=0.016)($ table 1$)$. On the other hand, there was no significant association between the different ages and the proportion of pregnant women who were HBsAg positive or negative $(\mathrm{p}=0.325)$ (table 1).

\section{Discussion}

The frequency of Kuwaiti and non-Kuwaiti pregnant women who were positive for HBsAg $(0.3 \%)$ was low, probably due to the effective $\mathrm{HBV}$ vaccination policy which was introduced in Kuwait in 1990. In infancy, the first dose of viral hepatitis $B$ vaccine is given on the first day of childbirth. The current prevalence of HBsAg carriers in pregnant women in Kuwait is similar to that in Spain (0.1\%) [12] and Northern and Central European counties $[13,14]$.

The prevalence of anti-rubella IgG in this study was comparable to the $85-90 \%$ in European women [15], in Turkey [16], and in Australia [17]. However, other studies revealed lower prevalences of anti-rubella IgG. In Nigerian pregnant women, $54.1 \%$ were positive for rubella IgG antibody [18], while the seroprevalence of rubella in pregnant women from Sri Lanka was 76\% [19], and in Russian pregnant women it was $77.5 \%$ [20].

The age range of 20-39 years in this study is similar to those of other studies $[16,17]$, thereby indicating a normal childbearing age in Kuwait. The high percentage of non-Kuwaiti pregnant women in this study is consistent with the population demographic in the country and probably indicates that non-Kuwaiti women use government clinics more frequently than do Kuwaiti women who tend to use private clinics.
That $473(11.6 \%)$ pregnant women were susceptible to rubella could indicate that, despite naturally acquired rubella and vaccination which was started 30 years ago, a high number of pregnant women in Kuwait remain susceptible to and hence at risk for congenital infections. It should be noticed that rubella vaccination is part of the measles, mumps, and rubella vaccination which is given to 1-year-old children.

Also, the finding that $11.6 \%$ of women in Kuwait were seronegative confirmed the findings of previous studies [21-23] in which 5.6, 7.7, and 4.2\%, respectively, were seronegative. The findings of this study further confirmed the prediction made by Hathout et al. [21] that in order to eliminate the $5-7 \%$ rate of females who remain susceptible because they are uninfected and therefore at risk, an alternative vaccination policy should be followed. That is, since premarital sex in Kuwait is assumed to be generally negligible and provided that they take contraceptives for 3 months, all women should be screened for rubella antibody at marriage and those found to be seronegative should be given the vaccine. It was hypothesized at that time that since naturally acquired infection could not eliminate the $5-7 \%$ rate of women who remain susceptible, vaccination, with a potential vaccine failure rate of $5 \%$, was unlikely to eliminate the rate of those who are susceptible. Indeed, in 1983 a rubella outbreak among pregnant women in Kuwait resulted in a high percentage of congenital infection and malformation [23]. Therefore, there is a need to include rubella antibody testing in the current routine premarital testing (which includes screening for HBsAg) that was introduced in Kuwait in 2009 , to define the rubella immune status of women at marriage, and to select those who are susceptible and hence offer vaccination. This would most likely prevent rubella infection in pregnancy in Kuwait.

\section{Conclusion}

Our results showed that the prevalence of both antirubella IgG and HBsAg among pregnant women in $\mathrm{Ku}-$ wait is relatively high. However, about $11.6 \%$ of pregnant women in Kuwait remain susceptible to rubella infection. This percentage can be reduced by screening all women for rubella antibody as a part of routine premarital testing and vaccinating women who are seronegative. 


\section{References}

1 Hamdan HZ, Abdelbagi IE, Nasser NM, et al: Seroprevalence of cytomegalovirus and rubella among pregnant women in western $\mathrm{Su}$ dan. Virol J 2011;11:8:217.

$>2$ Calimeri S, Capua A, La Fauci V, et al: Prevalence of serum anti-rubella virus antibodies among pregnant women in southern Italy. Int J Gynaecol Obstet 2012;116:211-213.

-3 Uyar Y, Balci A, Akcali A, et al: Prevalence of rubella and cytomegalovirus antibodies among pregnant women in northern Turkey. New Microbiol 2008;31:451-455.

$\checkmark 4$ Cutts FT, Robertson SE, Diaz-Ortega JL, et al: Control of rubella and congenital rubella syndrome (CRS) in developing countries. 1. Burden of disease from CRS. Bull World Health Organ 1997;75:55-68.

$\checkmark 5$ Linguissi LS, Nagalo BM, Bisseye C, et al: Seroprevalence of toxoplasmosis and rubella in pregnant women attending antenatal private clinic at Ouagadougou, Burkina Faso. Asian Pac J Trop Med 2012;5:810-813.

-6 Robertson SE, Featherstone DA, Gacic-Dobo $\mathrm{M}$, et al: Rubella and congenital rubella syndrome: global update. Rev Panam Salud Publica 2003; 14:306-315.

7 Montoya JG, Liesenfeld O: Toxoplasmosis. Lancet 2004;363:1965-1976.

$>8$ Bertolini DA, Pinho JR, Saraceni CP, et al: Prevalence of serological markers of hepatitis $B$ virus in pregnant women from Paraná State, Brazil. Braz J Med Biol Res 2006;39:10831090.
9 Zhang S, Li RT, Wang Y, et al: Seroprevalence of hepatitis B surface antigen among pregnant women in Jiangsu, China, 17 years after introduction of hepatitis B vaccine. Int J Gynaecol Obstet 2010;109:194-197.

10 Hyams KC: Risks of chronicity following acute hepatitis B virus infection: a review. Clin Infect Dis1995;20:992-1000.

11 Ganem D, Prince AM: Hepatitis B virus infection - natural history and clinical consequences. N Engl J Med 2004;350:1118-1129.

12 Salleras L, Domínguez A, Bruguera M, et al: Seroepidemiology of hepatitis B virus infection in pregnant women in Catalonia (Spain). J Clin Virol 2009;44:329-332.

13 Pol S, Corouge M, Fontaine H: Hepatitis B virus infection and pregnancy. Clin Res Hepatol Gastroenterol 2011;35:618-622.

14 Bracciale L, Fabbiani M, Sansoni A, et al: Impact of hepatitis $B$ vaccination in children born to HBsAg-positive mothers: a 20-year retrospective study. Infection 2009;37:340 343.

15 Mehta NM, Thomas RM: Antenatal screening for rubella - infection or immunity? BMJ 2002;13;325:90-91.

16 Aksakal FN, Maral I, Cirak MY, et al: Rubella seroprevalence among women of childbearing age residing in a rural region: is there a need for rubella vaccination in Turkey? Jpn J Infect Dis 2007;60:157-160.
17 Sathanandan D, Gupta L, Liu B, et al: Factors associated with low immunity to rubella infection on antenatal screening. Aust NZ J Obstet Gynaecol 2005;45:435-438.

18 Bukbuk DN, el Nafaty AU, Obed JY: Prevalence of rubella-specific IgG antibody in nonimmunized pregnant women in Maiduguri, north eastern Nigeria. Cent Eur J Public Health 2002;10:21-23.

19 Palihawadana P, Wickremasinghe AR, Perera $\mathrm{J}$ : Seroprevalence of rubella antibodies among pregnant females in Sri Lanka. Southeast Asian J Trop Med Public Health 2003;34:398404.

20 Odland $\varnothing$, Sergejeva IV, Ivaneev MD, et al: Seropositivity of cytomegalovirus, parvovirus and rubella in pregnant women and recurrent aborters in Leningrad County, Russia. Acta Obstet Gynecol Scand 2001;80:1025-1029.

21 Hathout H, Al-Nakib W, Lilley H, et al: Seroepidemiology of rubella in Kuwait: an alternative vaccination policy. Int J Epidemiol1978; 7:49-53.

22 Makhseed M, Moussa MA, Ahmed MA, et al: The status of rubella immunity among pregnant women in Kuwait: screening in childbearing age should be reintroduced. Acta Trop 2001;78:35-40.

23 Nordenfelt E, Al-Nakib W, Atack W, et al: The recent rubella epidemic in Kuwait: analysis of laboratory data and further preventive measures. J Kuwait Med Assoc 1984;18:6773. 